\title{
Physiology of rice and red rice plants in competition for nitrogen
}

\section{Fisiologia de plantas de arroz e arroz-vermelho em competição por nitrogênio}

\author{
Dirceu AGOSTINETTO'; Marcos André NOHATTO²; Camila Peligrinotti TAROUCO ${ }^{3}$; Jader Job FRANCO ${ }^{4}$; \\ Eliete de Fátima Ferreira da ROSA \\ 1Eng. Agr. Doutor em Fitotecnia. Universidade Federal de Pelotas, agostinetto.d@gmail.com \\ 2 Autor para correspondência; Eng. Agr. Doutor em Fitossanidade. IFC Campus Santa Rosa do Sul - Rua das \\ Rosas s/n - Caixa Postal 04 - CEP 88965-000 - Santa Rosa do Sul - SC, marcosnohatto@hotmail.com \\ ${ }^{3}$ Eng. Agr. Doutora em Fitossanidade. Universidade Federal de Pelotas. milatarouco@gmail.com \\ ${ }^{4}$ Eng. Agr. Mestre em Fitossanidade. Universidade Federal de Pelotas.jaderjobfranco@yahoo.com.br \\ ${ }^{5}$ Eng. Agr. Doutora em Manejo do Solo. IFC Campus Santa Rosa do Sul.eliete.rosa@ifc.edu.br
}

Recebido em: 14-10-2017; Aceito em: 04-04-2018

\begin{abstract}
Understanding the influence of nitrogen under the physiological behavior of rice and red rice in competition is critical to success in integrated weed management. In view of this, the objective of this work was to evaluate the physiological effects of the competition of rice and red rice submitted to different nitrogen concentrations. The experiments were conducted under greenhouse conditions in the 2011/12 crop year. The experimental design was completely randomized, with six replicates. The treatments were arranged in a factorial scheme, consisting of different combinations of the rice cultivar IRGA 424 and the red rice biotype, varying the ratios between them [intraspecific competition (100:0) and interspecific competition (50:50)]; and nitrogen doses (0,30,60,90, and $120 \mathrm{~g} \mathrm{dm}^{-3}$ ) added to the soil as urea, divided in two periods, at 15 and 53 days after emergence. The variables evaluated were: stomatal conductance of water vapor, photosynthetic rate, hydrogen peroxide and lipid peroxidation. The results show that, in general, when compared to intraspecific competition, interspecific competition causes greater oxidative stress and negatively interferes with photosynthesis even when plants are submitted to high (90 and $120 \mathrm{~g} \mathrm{dm}^{-3} \mathrm{~N}$ ) nitrogen doses. For red rice, in turn, it is the intraspecific competition that causes higher oxidative stress and loss of photosynthesis in plants under lower $\left(0 \mathrm{~g} \mathrm{dm}^{-3} \mathrm{~N}\right)$ and higher (90 and $120 \mathrm{~g} \mathrm{dm}^{-3} \mathrm{~N}$ ) nitrogen concentrations, respectively, in relation to interspecific competition.
\end{abstract}

Additional keywords: nitrogen fertilization; Oryza sativa; replacement series.

\section{Resumo}

A compreensão da influência do nitrogênio sob o comportamento fisiológico do arroz e arroz-vermelho em competição é fundamental para o sucesso no manejo integrado de plantas daninhas. Diante disso, o objetivo do trabalho foi avaliar os efeitos fisiológicos da competição de arroz-vermelho e arroz submetidos a diferentes concentrações de nitrogênio. Os experimentos foram conduzidos em casa de vegetação, no ano agrícola de 2011/2012. $O$ delineamento experimental utilizado foi o completamente casualizado, com seis repetições. Os tratamentos foram dispostos em esquema fatorial, sendo composto por diferentes combinações da cultivar de arroz IRGA 424 e de biótipo de arroz-vermelho, variando-se as proporções relativas de plantas por vaso [competição intraespecífica (100:0) e interespecífica (50:50)]; e doses de nitrogênio adicionadas ao solo (0;30;60; 90 e $120 \mathrm{~g} \mathrm{dm}^{-3}$ ) na forma de ureia, dividida em duas épocas, aos 15 e 53 dias após a emergência. As variáveis avaliadas foram: condutância estomática de vapores de água, taxa fotossintética, peróxido de hidrogênio e peroxidação lipídica. Os resultados evidenciam que, em geral, a competição interespecífica causa maior estresse oxidativo e interfere negativamente na fotossíntese, mesmo quando as plantas estão submetidas a altas (90 e $120 \mathrm{~g} \mathrm{dm}^{-3} \mathrm{de} \mathrm{N}$ ) doses de nitrogênio, comparado à competição intraespecífica. Enquanto para o arroz-vermelho, é a competição intraespecífica que causa maior estresse oxidativo e prejuízo na fotossíntese em plantas sob menores $\left(0 \mathrm{~g} \mathrm{dm}^{-3}\right.$ de $\mathrm{N}$ ) e maiores (90 e $120 \mathrm{~g} \mathrm{dm}^{-3}$ de N) concentrações de nitrogênio, respectivamente, em relação à competição interespecífica.

Palavras-chave adicionais: adubação nitrogenada; Oryza sativa; série de substituição.

\section{Introduction}

The rice crop has great social, economic and cultural importance, with around 741 million tonnes being produced worldwide (FAO, 2016). China is the largest producer (208 million tons), followed by India
(157 million tons) and Indonesia (70 million tons). Brazil is among the 10 largest producers, with production of 11.8 million tons in an area of 1.9 million hectares (CONAB, 2018).

Despite the prominent position worldwide in the rice crop, especially as result of the use of cultivars 
with high yield potential and the investment in technology, the level of productivity considered ideal for cultivation has not yet been reached. This is in part due to unsatisfactory weed control, especially red rice, the main weed affecting the crop (Agostinetto et al., 2001).

According to Dai et al. (2017), red rice presents faster emergence, higher production of adventitious (secondary) roots, and greater fresh mass compared to cultivated rice. The same authors also report that red rice has higher photosynthetic pigment content, net photosynthesis rate, stomatal conductance, intercellular $\mathrm{CO}_{2}$ concentration, transpiration rate, and kinetic parameters of chlorophyll fluorescence, with highest photosynthetic activity by the joint action of a larger antenna, more active reaction centers, and greater quantum yield for electron transfer; characteristics that aid the competitive ability of the weed against rice. However, it is known that the response to the interference with the crop goes beyond intrinsic characteristics of the plants, it also varies according to other factors such as nutritional management, especially of nitrogen.

When competition for nitrogen is established between the crop and the red rice, this reduces the nutrient availability for the first, which causes stress. A study showed that as soil nitrogen levels decrease, plants of the rice cultivar IR64 in competition with red rice biotypes from Malaysia, the Philippines, and Vietnam, reduce their leaf area and shoot dry matter (Chauhan \& Johnson, 2011). Notwithstanding, despite the possibility of verifying such responses through growth variables, the consequences of competition on plant physiology and the interaction with nitrogen fertilization have not yet been elucidated.

Understanding the influence of nitrogen fertilization under the physiological behavior of rice and red rice in competition is fundamental for the adequate choice of weed control strategies, and the nutritional management of the crop. Therefore, the objective of this work was to evaluate the physiological effects of the competition of rice and red rice submitted to different nitrogen concentrations.

\section{Material and methods}

The experiments were carried out under greenhouse conditions, in the 2011/12 crop year. The experimental units consisted of plastic pots with a volumetric capacity of four liters (height: $16 \mathrm{~cm}$; upper diameter: $21 \mathrm{~cm}$; bottom diameter: $17 \mathrm{~cm}$; not perforated in the base), filled with samples of Red-Yellow Argisol, with sandy loam texture $(\mathrm{pH}$ in water $=5.7$; O.M. = $17 \mathrm{~g} \mathrm{dm}^{-3} ; \mathrm{P}=22.6 \mathrm{mg} \mathrm{dm}^{-3} ; \mathrm{K}=112 \mathrm{mg} \mathrm{dm}^{-3}$; $\mathrm{Ca}=3.1 \mathrm{cmol}_{\mathrm{c}} \mathrm{dm}^{-3} ; \mathrm{Mg}=1.1 \mathrm{cmol}_{\mathrm{c}} \mathrm{dm}^{-3} ; \mathrm{H}+\mathrm{Al}=$ $=2.8 \mathrm{cmol}_{\mathrm{c}} \mathrm{dm}^{-3} ; \mathrm{CEC}$ (cation-exchange capacity) = $=7.1 ; \mathrm{Al}=0.1 \mathrm{cmol}_{\mathrm{c}} \mathrm{dm}^{-3} ;$ base saturation $=61 \%$; and aluminum saturation $=2.0 \%$ ). The experiments were carried out in a completely randomized experimental design, with six replicates, using seeds of the rice cultivar IRGA 424. Red rice seeds were obtained from plants of a rice farm in the municipality of Rio Grande, in the southern region of the state of Rio Grande do Sul.

Firstly, a preliminary experiment with rice and red rice in monoculture was carried out to determine the population of plants $\mathrm{m}^{-2}$ from which the shoot dry matter (SDM) per unit area $\left(\mathrm{g} \mathrm{m}^{-2}\right)$ becomes independent of the population, according to the "constant yield law" (Radosevich et al., 2007). The tested populations were 4, 8, 16, 32, 64, and 128 plants per pot (equivalent to $143 ; 286 ; 571 ; 1,143 ; 2,286$; and 4,571 plants $\mathrm{m}^{-2}$ ).

The variable SDM was quantified at 45, 60, and 75 days after emergence (DAE) by weighing the shoots of plants after drying in a greenhouse with forced air circulation at $60^{\circ} \mathrm{C}$ for 96 hours. For data analysis, the reciprocal production was used to determine the population of plants where SDM became constant. Final yield was obtained with a mean population of 32 plants per pot, equivalent to 1,143 plants $\mathrm{m}^{-2}$; and the time defined for the collection of plants was at 60 DAE (data not shown).

The second experiment was set up in a factorial scheme, where factor $A$ was composed of different combinations of the rice cultivar IRGA 424 and the red rice biotype, varying the ratios between them [intraspecific competition (100:0), and interspecific competition (50:50)]; and factor $B$ was composed of nitrogen doses added to the soil $\left(0,30,60,90\right.$, and $\left.120 \mathrm{~g} \mathrm{dm}^{-3}\right)$ in the form of urea, incorporated with water one day after application from the flooding of the experimental units, thus with no nutrient losses.

Nitrogen application was divided into two equal parts, one performed on dry soil at 15 days after emergence (DAE), at the beginning of tillering, and another at $53 \mathrm{DAE}$. At sowing, fertilization was performed at 25 and $20 \mathrm{~g} \mathrm{dm}^{-3}$ equivalent of $\mathrm{P}_{2} \mathrm{O}_{5}$ and $\mathrm{K}_{2} \mathrm{O}$, respectively, in the form of triple superphosphate and potassium chloride incorporated into the soil.

At $60 \mathrm{DAE}$, evaluations were performed in the last fully expanded leaf, in the middle third of the stem, between 8 and 10 o'clock in the morning, using the portable meter IRGA, brand LI-COR, model LI-6400. At that time, the stomatal conductance of water vapor

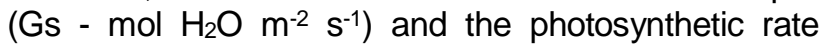
$\left(\mathrm{A}-\mu \mathrm{mol} \mathrm{CO}_{2} \mathrm{~m}^{-2} \mathrm{~s}^{-1}\right.$ ) were determined. Subsequently, the leaves of the rice or red rice plants from each experimental unit were collected separately and stored at $-80{ }^{\circ} \mathrm{C}$ until the moment of quantification of the other variables that will be described next.

Cell/tissue damage was determined from the hydrogen peroxide $\left(\mathrm{H}_{2} \mathrm{O}_{2}\right)$ content, as described by Alexieva et al. (2001), and thiobarbituric acid reactive species (TBARS) damage determined via malonic aldehyde (MDA) concentration, as described by Health \& Packer (1968). To carry out these analyses, $0.2 \mathrm{~g}$ of leaves were macerated with liquid nitrogen, homogenized in $2 \mathrm{~mL}$ of $0.1 \%$ trichloroacetic acid $(\mathrm{m} / \mathrm{v})$, and centrifuged at $14,000 \mathrm{rpm}$ for $20 \mathrm{~min}$. For the quantification of $\mathrm{H}_{2} \mathrm{O}_{2}, 0.2 \mathrm{~mL}$ aliquots of the supernatant were 
added in $0.8 \mathrm{~mL}$ of $10 \mathrm{mM}$ phosphate buffer $(\mathrm{pH} 7.0)$ and $1 \mathrm{~mL}$ of $1 \mathrm{M}$ potassium iodide. The solution was allowed to stand for $10 \mathrm{~min}$ at room temperature, with the absorbance being read at $390 \mathrm{~nm}$. The $\mathrm{H}_{2} \mathrm{O}_{2}$ concentration was determined using the standard curve and expressed in milimol per gram of fresh weight $\left(\mathrm{mM} \mathrm{g}^{-1} \mathrm{FW}\right)$.

To determine TBARS, $0.5 \mathrm{~mL}$ aliquots of the supernatant, as described above, were added to $1.5 \mathrm{~mL}$ of $0.5 \%(\mathrm{~m} / \mathrm{v})$ thiobarbituric acid (TBA) and $10 \%(\mathrm{w} / \mathrm{v})$ trichloroacetic acid, and incubated at $90{ }^{\circ} \mathrm{C}$ for $20 \mathrm{~min}$. The reaction was stopped in an ice bath for $10 \mathrm{~min}$. The absorbance was read at $532 \mathrm{~nm}$, subtracting the non-specific absorbance at $600 \mathrm{~nm}$. The MDA concentration was calculated using the absorbance coefficient of $155 \mathrm{mM} \mathrm{cm}^{-1}$, the results being expressed in $\mathrm{nM} \mathrm{MDA} \mathrm{g} \mathrm{g}^{-1} \mathrm{FW}$.

The data were analyzed for their normality
(Shapiro Wilk test) and later submitted to analysis of variance $(p \leq 0.05)$. In the case of statistical significance for the factor competitors, the data were compared by the mean confidence interval, whereas for the factor nitrogen dose, a polynomial regression study was performed $(p \leq 0.05)$.

\section{Results and discussion}

There was interaction of the factors ratio of competing plants and nitrogen doses, in rice and red rice, for all evaluated variables (Figure 1 and 2). The data obtained for the variables were adjusted to a quadratic equation, and the values of the coefficient of determination $\left(R^{2}\right)$ ranged from 0.75 to 0.98 , showing satisfactory adjustment of the data to the model.
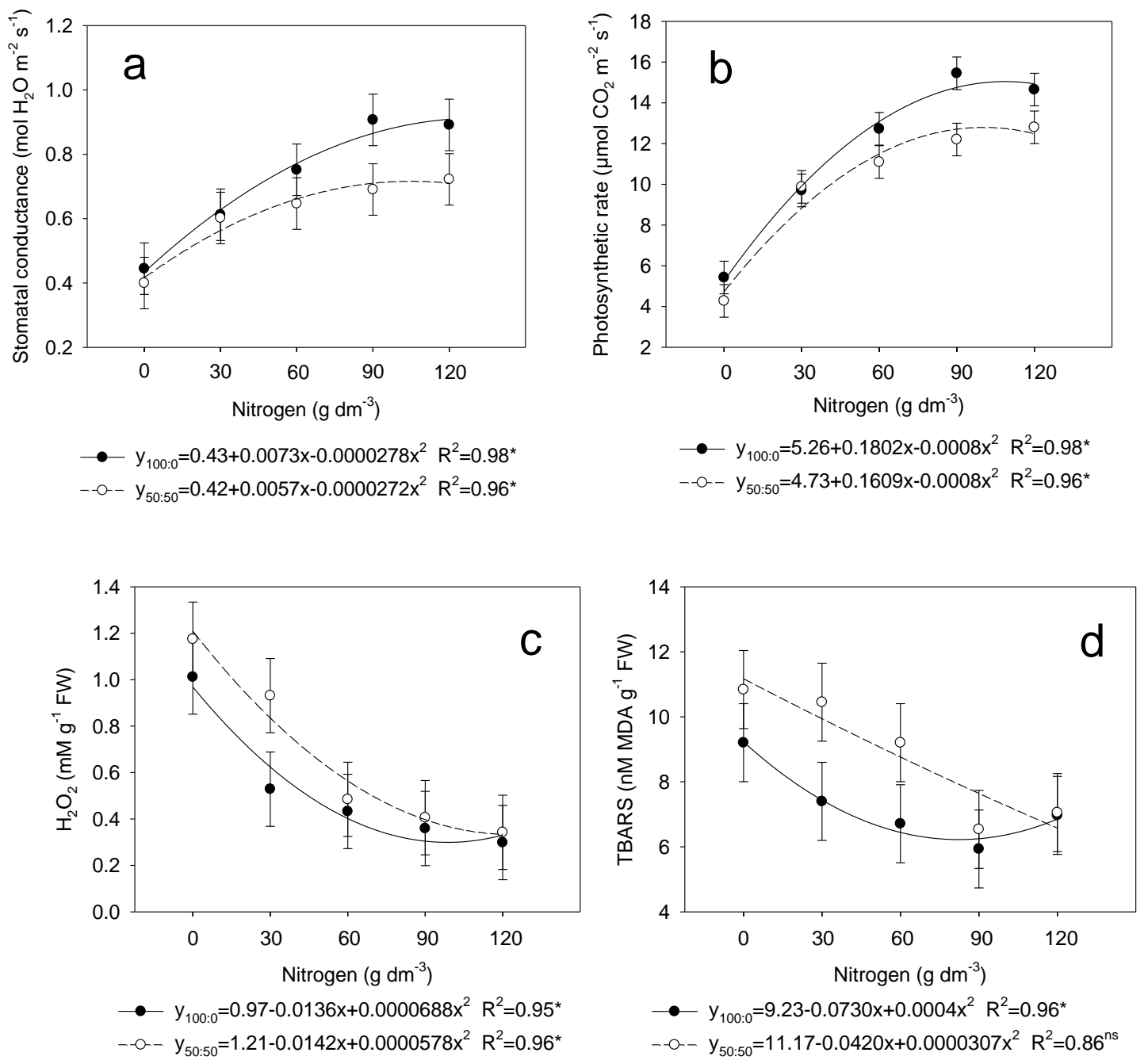

Figure 1 - Stomatal conductance (Gs) (a), photosynthetic rate (b), hydrogen peroxide $\left(\mathrm{H}_{2} \mathrm{O}_{2}\right)$ (c) and thiobarbituric acid (TBARS) (d) of rice IRGA 424 under monoculture (100:0 - intraspecific competition) and competition with red rice biotype (50:50 - interspecific competition), submitted to different doses of nitrogen, evaluated at 60 days after emergence. The dots represent the mean values of the replicates and the bars, the respective confidence intervals of the mean. Regression significance $\left(^{*}\right)(p \leq 0.05)$ and non-significance $\left({ }^{n s}\right)(p>0.05)$. 
It was observed that the rice plants competing with red rice had lower values of stomatal conductance and photosynthetic rate at the doses of 90 and $120 \mathrm{~g} \mathrm{dm}^{-3} \mathrm{~N}$ compared to intraspecific competition of
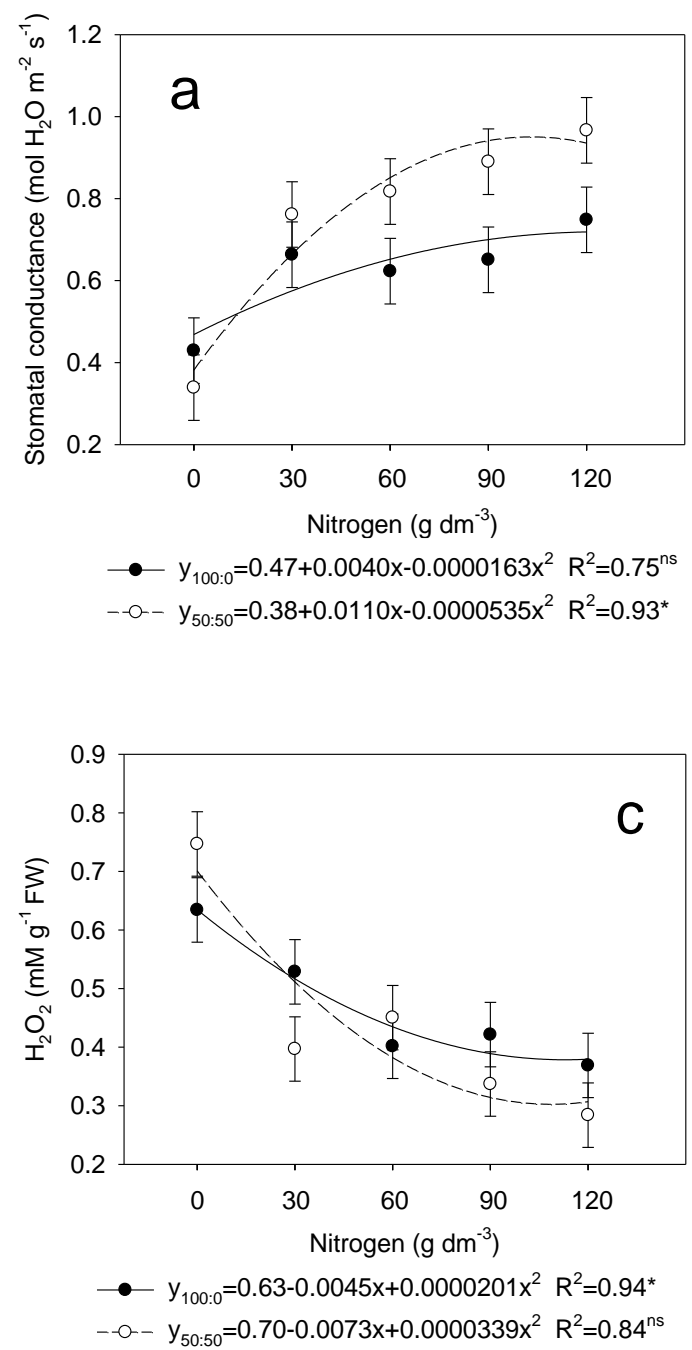

the crop (Figure 1), whereas in the same doses, red rice plants in competition with the crop showed higher values of the variables compared to the intraspecific competition of the weed (Figure 2).
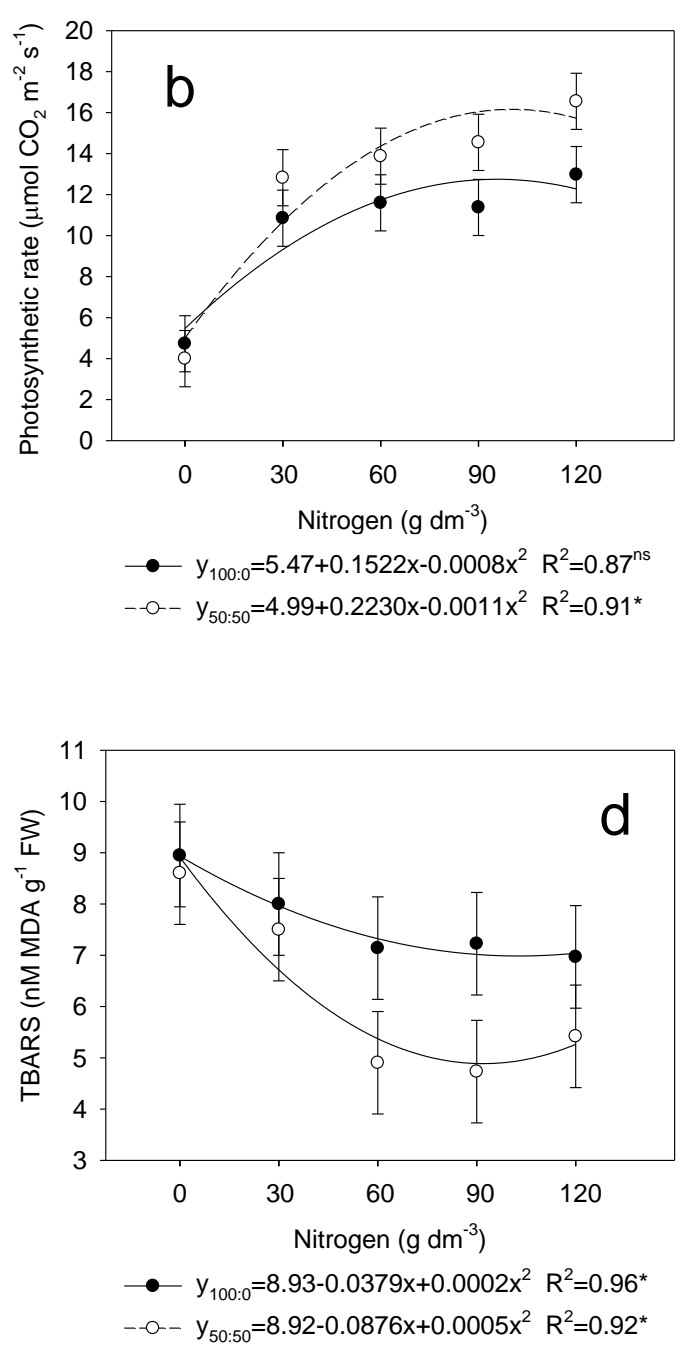

Figura 2 - Stomatal conductance (Gs) (a), photosynthetic rate (b), hydrogen peroxide $\left(\mathrm{H}_{2} \mathrm{O}_{2}\right)$ (c) and thiobarbituric acid (TBARS) (d) of red rice biotype under monoculture (100:0 - intraspecific competition) and competition with rice IRGA 424 (50:50 - interspecific competition), submitted to different doses of nitrogen, evaluated at 60 days after emergence. The dots represent the mean values of the replicates and the bars, the respective confidence intervals of the mean. Regression significance $\left(^{*}\right)(p \leq 0.05)$ and non-significance $\left({ }^{n s}\right)(p>0.05)$.

It is believed that the greater development of red rice at higher doses decreases the interception of light by the crop, caused by greater shading. This limitation caused a stress condition in rice, resulting in decreased stomatal conductance and, consequently, lower photosynthetic activity.

From the equations, it was verified that the rice and red rice plants presented increased stomatal conductance and photosynthetic rate when submitted to increasing nitrogen doses (Figure 1 and 2). For stomatal conductance, the maximum points for rice and red rice in interspecific competition were 104.7 and $102.8 \mathrm{~g} \mathrm{dm}^{-3} \mathrm{~N}$, corresponding to 0.71 and $0.95 \mathrm{~mol} \mathrm{H}_{2} \mathrm{O} \mathrm{m} \mathrm{m}^{-2} \mathrm{~s}^{-1}$ of the variable, respectively, while in the evaluation of intraspecific competition of the plants, the estimated values were higher than the maximum dose tested in the study.

For the photosynthetic rate, the maximum point for rice plants under intraspecific and interspecific competition were obtained at the doses of 112.6 and $100.6 \mathrm{~g} \mathrm{dm}^{-3} \mathrm{~N}$, providing 15.4 and $12.8 \mu \mathrm{mol} \mathrm{CO}_{2} \mathrm{~m}^{-2} \mathrm{~s}^{-1}$ of the variable, respectively (Figure 1). For red rice in intraspecific and interspecific competition, the doses that reached the maximum point were 95.1 and $101.4 \mathrm{~g} \mathrm{dm}^{-3}$, indicating a photosynthetic rate of 12.7 and $16.3 \mu \mathrm{mol} \mathrm{CO} 2 \mathrm{~m}^{-2} \mathrm{~s}^{-1}$, respectively (Figure 2).

The increase in the physiological variables as a function of the increase in nutrient doses is probably 
due to the positive correlation between plant nitrogen content and chlorophyll biosynthesis, in addition to the rubisco enzyme activity and ATP synthase, as well as the chloroplast size and thylakoid content (Laza et al., 1993; Schadchina \& Dmitrieva, 1995; Redillas et al., 2011). On the other hand, nutrient deficiency leads to decreased $\mathrm{CO}_{2}$ assimilation capacity, photosynthetic rate, stomatal conductance, and quantum yield of photosystem II in rice plants (Kumagai et al., 2009).

For the variables that evaluate oxidative stress, it was observed that rice plants submitted to interspecific competition, and red rice in intraspecific competition presented higher values of $\mathrm{H}_{2} \mathrm{O}_{2}$ at the dose of $30 \mathrm{~g} \mathrm{dm}^{-3} \mathrm{~N}$ (Figure 1 and 2). It is hypothesized that due to the limitation of nitrogen in the experimental unit, it was established a condition of intense dispute for the nutrient in the aforementioned associations of plants, unbalancing the formation of reactive oxygen species in the plants and, consequently, increasing $\mathrm{H}_{2} \mathrm{O}_{2}$. The present results corroborate with those found by Afifi and Swanton (2012), who observed an accumulation in $\mathrm{H}_{2} \mathrm{O}_{2}$ content under competition.

$\mathrm{H}_{2} \mathrm{O}_{2}$ can inhibit the synthesis of proteins of photosystem II (Takahashi \& Murata, 2008), present negative correlation with the activity of the rubisco enzyme (Zhou et al., 2007), and cause damage to lipids and other components such as nucleic acids, essential for cell activity and integrity, suggesting that such events are also activated during competition.

It was also verified that rice and red rice plants presented a decrease of the $\mathrm{H}_{2} \mathrm{O}_{2}$ content when submitted to the increasing nitrogen doses. For rice in intraspecific competition, a minimum point of $98.8 \mathrm{~g} \mathrm{dm}^{-3} \mathrm{~N}$ was observed, which corresponds to $0.29 \mathrm{mM} \mathrm{g}^{-1}$ of the variable, whereas for interspecific competition it was not possible to characterize the minimum point for the crop, since the estimated doses are higher than the doses used in the study (Figure 1). Regarding the weed, in intraspecific and interspecific competition, we observed a minimum point of 111.9 and $107.6 \mathrm{~g} \mathrm{dm}^{-3} \mathrm{~N}$, representing 0.38 and $0.31 \mathrm{mM} \mathrm{g}^{-1}$ of the variable, respectively (Figure 2).

These results are probably related to the decrease of the $\mathrm{CO}_{2}$ assimilation capacity induced by nutrient deficiency, which restricts the consumption of ATP and NADPH, resulting in the production of reactive oxygen species such as $\mathrm{H}_{2} \mathrm{O}_{2}$ (Skillman \& Osmond, 1998). This study confirms the results obtained in this research, demonstrating that nitrogen deficiency can increase $\mathrm{H}_{2} \mathrm{O}_{2}$ in rice leaves, indicating oxidative stress (Kumagai et al., 2009; Lin et al., 2011).

In the evaluation of lipid peroxidation, it was observed that the rice plants submitted to competition with red rice had higher MDA values at the doses of 30 and $60 \mathrm{~g} \mathrm{dm}^{-3} \mathrm{~N}$ compared to intraspecific competition (Figure 1). Moreover, it was verified that the weed under monoculture also showed higher peroxidation at the doses of 60 and $90 \mathrm{~g} / \mathrm{dm}^{3} \mathrm{~N}$ in relation to interspecific competition (Figure 2).

MDA is the product of lipid peroxidation, con- sequently, the higher content of this compound indicates oxidative stress (Liu et al., 2009). Thus, it is hypothesized that competition for nitrogen may induce the production of free radicals that oxidize the phospholipid components of cell membranes, leading to an increase in the contents of the variable. Recently, a study has also demonstrated the competition capacity to cause oxidative stress, with an increase in the MDA content being detected in soybean plants competing with susceptible and glyphosate-resistant ryegrass (Agostinetto et al., 2016).

Based on the equations, it was verified that rice and red rice plants presented a reduction in the MDA content when submitted to increasing nitrogen doses, reaching for the crop in intraspecific competition, a minimum point of $91.2 \mathrm{~g} \mathrm{dm}^{-3} \mathrm{~N}$, which corresponds to $5.9 \mathrm{nM} \mathrm{MDA} \mathrm{g}^{-1} \mathrm{FW}$ of the variable; for interspecific competition, it was not possible to identify the minimum point, since the estimated doses are higher than the maximum dose in the study (Figure 1). On the other hand, for the weed in intraspecific and interspecific competition, the minimum points were obtained at the doses of 94.7 and $87.6 \mathrm{~g} \mathrm{dm}^{-3} \mathrm{~N}$, indicating 7.1 and $5.1 \mathrm{nM} \mathrm{MDA} \mathrm{g}^{-1} \mathrm{FW}$ of the variable, respectively (Figure 2).

\section{Conclusions}

In the rice crop, when compared to intraspecific competition, interspecific competition causes greater oxidative stress and negatively interferes with photosynthesis even when the plants are submitted to high nitrogen doses (90 and $120 \mathrm{~g} \mathrm{dm}^{-3} \mathrm{~N}$ ).

For red rice, it is the intraspecific competition that causes greater oxidative stress and loss of photosynthesis in plants under lower $\left(0 \mathrm{~g} \mathrm{dm}^{-3} \mathrm{~N}\right)$ and higher $(90$ and $120 \mathrm{~g} \mathrm{dm}^{-3} \mathrm{~N}$ ) nitrogen concentrations, respectively, in relation to interspecific competition.

\section{References}

Afifi M, Swanton C (2012) Early physiological mechanisms of weed competition. Weed Science 60 (4):542$-551$.

Agostinetto D, Fleck NG, Rizzardi MA, Merotto Júnior A, Vidal RA (2001) Arroz vermelho: ecofisiologia e estratégias de controle. Ciência Rural 31(2):341-349.

Agostinetto D, Oliveira C, Langaro AC, Nohatto MA, Manica-Berto R (2016) Change in physiological features in ryegrass biotypes in competition with soybean due resistance to glyphosate. Planta Daninha 34(3):517-526.

Alexieva V, Sergiev I, Mapelli S, Karanov E (2001) The effect of drought and ultraviolet radiation on growth and stress markers in pea and wheat. Plant, Cell \& Environment 24 (12):1337-1344. 
Chauhan BS, Johnson DE (2011) Competitive interactions between weedy rice and cultivated rice as a function of added nitrogen and the level of competition. Weed Biology and Management 11(4):202-209.

CONAB - Companhia Nacional de Abastecimento. Séries históricas para 0 arroz. Disponível em <https://www.conab.gov.br/info-agro/safras/seriehistorica-das-safras> Acesso em 15 jan 2018.

Dai L, Song X, He B, Valverde BE, Qiang S (2017) Enhanced photosynthesis endows seedling growth vigour contributing to the competitive dominance of weedy rice over cultivated rice. Pest management science 73 (7):1410-1420.

FAO - Food and Agriculture Organization of the United Nations (2016) Disponível em <http://faostat.fao.org/site/339/default.aspx> Acesso em 14 out 2017.

Health RL, Packer L (1968) Photoperoxidation in isolated chloroplasts. I. Kinetics and stoichiometry of fatty acid peroxidation. Archives of Biochemistry and Biophysics 125(1):189-198.

Kumagai E, Araki T, Ueno O (2009) Effect of nitrogendeficiency on midday photoinhibition in flag leaves of different rice (Oryza sativa L.) cultivars. Photosynthetica 47(2):241-246.

Laza RC, Bergman B, Vergara BS (1993) Cultivar differences in growth and chloroplast ultrastructure in rice as affected by nitrogen. Journal of Experimental Botany 44(11):1643-1648.

Lin Y-L, Chao Y-Y, Huang W-D, Kao CH (2011) Effect of nitrogen deficiency on antioxidant status and $\mathrm{Cd}$ toxicity in rice seedlings. Plant Growth Regulation 64(3):263-273.
Liu Z-J, Zhang X-L, Bai J-G, Suo B-X, Xu P-L, Wang L (2009) Exogenous paraquat changes antioxidant enzyme actives and lipid peroxidation in droughtstressed cucumber leaves. Scientia Horticulturae 121(2):138-143.

Radosevich SR, Holt JS, Ghersa CM (2007) Ecology of weeds and invasive plants: relationship to agriculture and natural resource management. Hoboken. 454p.

Redillas MCFR, Jeong JS, Strasser RJ, Kim YS, Kim JK (2011) JIP analysis on rice (Oryza sativa cV Nipponbare) grown under limited nitrogen conditions. Journal of the Korean Society for Applied Biological Chemistry 54(5):827-832.

Schadchina TM, Dmitrieva VV (1995) Leaf chlorophyll content as a possible diagnostic mean for the evaluation of plant nitrogen uptake from the soil. Journal of Plant Nutrition 18(7):1427-1437.

Skillman JB, Osmond CB (1998) Influence of nitrogen supply and growth irradiance on photoinhibition and recovery in Heuchera americana (Saxifragaceae). Physiologia Plantarum 103(4):567-573.

Takahashi S, Murata N (2008) How do environment stresses accelerate photoinhibition? Trends Plant Science 13(4):178-182.

Zhou Y, Lam HM, Zhang J (2007) Inhibition of photosynthesis and energy dissipation induced by water and high light stresses in rice. Journal of Experimental Botany 58(5):1207-1217. 